\title{
Quantification of damage and yield losses caused by Root-knot nematode in lettuce in Brazil
}

\author{
Cuantificación de daños y pérdidas de rendimiento causadas \\ por el nematodo agallador en un cultivo de lechuga en Brasil
}

\author{
Lilian Katiany C. Rabello ${ }^{*}$, Ângelo Oliveira Gonçalves ${ }^{1}$, Tatiane Paulino da Cruz ${ }^{1}$, \\ Fernando Domingo Zinger ${ }^{1}$, Waldir Cintra de Jesus Júnior ${ }^{1}$, Lilian Lagen Rodrigues ${ }^{1}$, \\ Antônio Fernando de Souza ${ }^{2}$, Willian Bucker Moraes ${ }^{1}$, and Fábio Ramos Alves ${ }^{1}$.
}

\begin{abstract}
The objective of this work was to quantify damage and yield losses in lettuce parasitized by Meloidogyne javanica, as well as the growth characteristics of naturally cultivated field plants infested by this pathogen. The experimental area consisted of four seedbeds of $10.0 \times 1.60 \mathrm{~m}$ cultivated with 160 plants in each, totaling 640 plants. The damages and yield loss were quantified in four evaluations (Ev1, Ev2, Ev3, and Ev4), with each evaluation corresponding to a cultivation cycle. The four plantings were made in the consecutive form. The fresh mass weight and dry mass weight (FMW and DMW, respectively), gall number (GN), and final population of the nematodes (FP) were evaluated. The population increase of $M$. javanica caused a reduction in the FMW and DMW in all evaluations. In Ev1 and Ev2, 100\% of the plants were commercialized. In Ev3 and Ev4, 7\% and 65\% of the plants, respectively, could not be commercialized. The Ev4 was completely unviable since the produce had losses of U\$ 7.42; U\$ 23.19 and U\$ 1,484.10 for the cultivation of 640;2,000 and 128,000 plants, respectively. The economic threshold in Ev4 was 10,151 nematodes/plant or 109 galls/plant.
\end{abstract}

Keywords: Lactuca sativa, Meloidogyne javanica, field.

\section{RESUMEN}

El objetivo de este trabajo fue cuantificar el daño agronómico en un cultivo de lechugas parasitadas por Meloidogyne javanica y caracterizar el crecimiento de plantas cultivadas en un campo infestado por este patógeno. El estudio se hizo en cuatro camas de $10.0 \times 1.60$ m cultivadas con 160 plantas en cada una, totalizando 640 plantas por cada ciclo de cultivo. Se hicieron cuatro tratamientos (Ev1, Ev2, Ev3 y Ev4), correspondientes a un ciclo de cultivo. Las cuatro plantaciones se realizaron de forma consecutiva y se seleccionaron 100 plantas al azar para cuantificar el efecto del nematodo en las lechugas. Los parámetros evaluados fueron peso fresco $(P M F)$, peso seco (PMS), número de agallas $(N G)$ y la población final de nematodos (PF). El aumento de la población de M. javanica provocó una reducción de PMF y PMS en todas las evaluaciones. En Ev1 y Ev2 se vendió el 100\% de las plantas. En Ev3 y Ev4 hubo un 7\% y un 65\% de las plantas, respectivamente, que no pudieron venderse. El cuarto ciclo de cultivo (Ev4) resultó completamente inviable, ya que las pérdidas fueron de U \$7,42; U \$23,19 y U \$1.484,10 para el cultivo de 640, 2.000 y 128.000 plantas, respectivamente. El umbral económico en Ev4 fue de 10.151 nematodos / planta o 109 agallas / planta Palabras clave: Lactuca sativa, Meloidogyne javanica, campo.

\section{Introduction}

Lettuce (Lactuca sativa L.) is among the ten most valued leafy vegetables for natural consumption in Brazil, cultivated in all regions of this country
(Ceasa-ES, 2018). Together with the tomato, it is the most used vegetable in the Brazilian kitchen.

Lettuce is a plant that is susceptible to root-knot nematodes, Meloidogyne spp. Goeldi 1887 (Rodrigues et al., 2016), and depending on the cultivar, population

1 Federal University of Espirito Santo, Department of Agronomy, Alegre-ES. Brazil, CEP 29500-000.

2 Federal Institute of Education, Science and Technology of Santa Espirito Santo (IFES), Campus Santa Teresa, ES, Brazil, CEP 29660-000.

* Corresponding author: lilianzinger01@gmail.com 
density, virulence of the nematode, environmental conditions, the interaction between nematode and other pathogens, plant physiological conditions, and the soil organic material content, the plants may suffer damage quantitatively and qualitatively and yield losses caused by these pathogens in lettuce are estimated between 10 and 100\% (Jesus Junior et al., 2014; Rodrigues et al., 2016).

According to Abd-Elgaward and Askary (2015), to avoid damage, the ideal is to maintain the nematode population below the economic threshold (ET), defined as the intensity of the disease at which the benefit of control is equal to its cost. However, for this definition to be operational and for integrated management to be viable, it is necessary to quantify the damage and yield losses caused by phytonematodes.

In Brazil, research on the effects of nematodes on lettuce cultivated in the field is rare. Some research has been done on lesion nematodes, Pratylenchus spp., Filipjev 1936 (Potter \& Olthof, 1974); however, the majority has been done in other countries with the root-knot nematodes Meloidogyne spp., (Viaene \& Abawi, 1998). This information emphasizes the importance of quantifying the damage and yield losses in commercially exploited crops parasitized by Meloidogyne spp., to guide the producers decisionmaking in managing these pathogens.

The objective of this work was to quantify the damage and yield losses in lettuce attacked by $M$. javanica (Treub 1885) Chitwood 1949, in field conditions.

\section{Materials and Methods}

The experiment was carried out in a field cultivated with lettuce cv. Vitória de Santo Antão naturally infested with $M$. javanica in Iúna Municipality, Espírito Santo State, Brazil. The area is at 649 meters altitude, $20^{\circ} 23$ ' $41^{\prime}$ ' 'south latitude and $41^{\circ} 32^{\prime} 31$ '" west longitude.
The region's climate is classified as Cwahumid subtropical (Köppen climate classification), with average annual temperatures varying from 8 to $27^{\circ} \mathrm{C}$.

The maximum and minimum air temperature and mean precipitation were monitored in the experiment region through automatic surface stations provided by the Instituto Capixaba de Pesquisa, Assistência Técnica e Extensão Rural of Espirito Santo - Incaper.

Table 1 shows the experimental periods, the air temperatures and the mean precipitation during the crop cycles.

The soil where the experiments were carried out was classified as medium texture, presenting $635.60 \mathrm{~g} / \mathrm{kg}$ of sand; $53.62 \mathrm{~g} / \mathrm{kg}$ silt; $310.19 \mathrm{~g} / \mathrm{kg}$ clay and $\mathrm{pH}=5.82$.

The experimental area consisted of four $10.0 \mathrm{~m} \mathrm{x}$ $1.60 \mathrm{~m}$ seedbeds, cultivated with 160 lettuce plants each $\left(10\right.$ plants $\left./ \mathrm{m}^{2}\right)$, totaling 640 plants in each crop cycle.

The lettuce seedlings for conducting the experiments were produced in situ by the farmer, owner of the property, and taken to the field 20 days after sowing.

Fertilization was done in each cultivation cycle, according to recommendations for cultivation. Other cultural treatments, such as irrigation, were done according to the recommendations for the crop.

\section{Identification of root-knot-nematode species}

The identification of the species of Meloidogyne present in the naturally infested area was made by using the electrophoresis technique of esterase isoenzyme (Carneiro and Almeida, 2001). For that, before the experiment 30 plants with root galls were collected randomly and 10 females were taken from each plant for identification, resulting in a total of 300 analyzed females.

Table 1. Duration of four experiments with lettuce crop cv. Vitória Santo Antão in Iúna, ES,

maximum and minimum temperatures of the air, and mean precipitation during the respective experimental periods.

\begin{tabular}{cccccc}
\hline $\begin{array}{c}\text { Crop } \\
\text { cycles }\end{array}$ & Experimental period & $\begin{array}{c}\text { Duration of the experimental } \\
\text { period (days) }\end{array}$ & $\begin{array}{c}\text { Maximum and minimum } \\
\text { T of the air }\left({ }^{\circ} \mathrm{C}\right)\end{array}$ & $\begin{array}{c}\text { Average precipitation } \\
\text { (mm) }\end{array}$ \\
\hline \multicolumn{2}{c}{ Beginning } & End & & & \\
\hline $1^{\text {st }}$ & $02 / 07 / 2009$ & $17 / 08 / 2009$ & 46 & 13 to 22 & 14 \\
$2^{\text {nd }}$ & $04 / 09 / 2009$ & $18 / 10 / 2009$ & 44 & 15 to 24 & 53 \\
$3^{\text {rd }}$ & $01 / 11 / 2009$ & $18 / 12 / 2009$ & 48 & 18 to 24 & 214 \\
$4^{\text {th }}$ & $06 / 01 / 2010$ & $20 / 02 / 2010$ & 45 & 23 to 30 & 255 \\
\hline
\end{tabular}




\section{Determination of the initial population of $M$. javanica ( $\mathrm{Pi}$ ) in the experimental area}

The $\mathrm{Pi}$, expressed in number of second stage juveniles (J2) in $100 \mathrm{~mL}$ of soil, was determined by the Jenkins technique (1964). Therefore, 30 soil samples were randomly collected at a depth of $0-20$ $\mathrm{cm}$ in each seedbed. These samples were mixed and homogenized, forming 4 composite samples.

The samples were packed in polyethylene bags, labeled, and immediately brought to the nematology laboratory for analysis.

\section{Quantification of the damage}

Four evaluations were done (Ev1, Ev2, Ev3 and Ev4). Each evaluation corresponded to a complete cycle of the lettuce crop. The four plantings were done consecutively. The first planting was only done after the land had been fallow for four months.

In each evaluation, a sample of 100 randomly selected plants from a total of 640 plants with different levels of nematode infestations ( 0 at the maximum level) was taken.

Immediately after collection, the weight of the fresh material of the leaves (FMW), the number of leaves (NL) and the weight of the stalk (WS) were determinated. Leaves were dried in an incubator at $70{ }^{\circ} \mathrm{C}$ for 72 hours, to measure the weight of the dry material (DMW). The gall number (GN) and the final population of the nematodes (FP) in the infected plants were evaluated according to the method proposed by Bonetti \& Ferraz (1981).

Reductions in FMW and DMW were compared to plants free of nematodes (level zero of the pathogen).

Data was statistically analyzed through two distinct procedures. When we considered each evaluation individually, the data were analyzed by linear regression, with the model chosen by the coefficient of determination $\left(\mathrm{R}^{2}\right)$ and significance of the regression coefficient (B1). The KruskalWallis test was used for analyses involving all the evaluations. These analyses were done using the BioEstat 5.0 software at the 5\% probability level.

\section{Quantification of yield losses}

The farmer, owner of the experimental area used in this study, sells 2,000 heads of lettuce each week. Thus, this amount was calculated as the potential weekly loss of the farmer, in addition to the loss estimates of 640 heads of lettuce (total plants cultivated in the experimental area) and 128,000 heads (total plants cultivated in 1 ha). The cost of producing 2,000 heads of lettuce was provided by the farmer (Table 2), with the commercial value of these plants determined at a local market. The production values of 640 to 128,000 plants were estimated as a function of this information. Moreover, the calculation to estimate yield losses was based on commercialization data provided by the Central Market (Central de Abastecimento) of Espírito Santo State, Brazil (Ceasa-ES). Following the criteria of Ceasa-ES, lettuce plants weighing less than $300 \mathrm{~g}$ are not well-accepted, but are sold when there is little supply of this vegetable in the market. Plants with a weight less than $200 \mathrm{~g}$ are not sold at all. In the present work only those plants weighing more than $200 \mathrm{~g}$ were considered to have commercial potential. The plants were divided into four categories based on the weight of fresh material (g): plants less than $100 \mathrm{~g}$ (category 1), plants between 100.01 and $200 \mathrm{~g}$ (category 2), 200.01 to $300 \mathrm{~g}$ (category 3 ) and plants weighing more than $300 \mathrm{~g}$ (category 4).

We estimated the farmer's yield loss as a function of the parasitism of the nematodes on the plants. The economic threshold (ET) was estimated based on the equation generated by regression involving the FMW and/or GN and FP. The ET was calculated only for Ev4, since there was insufficient damage to cause yield losses in Ev1, Ev2 and Ev3.

To determine yield losses (Table 6), we calculated, for each evaluation, the income obtained from the commercially viable plants of categories 3 and 4 (U\$ 0.17/plant) and subtracted the cost of producing the entire crop.

Table 2. Cost estimates of producing lettuce cv. Vitória de Santo Antão, calculated for a) 2,000 heads of lettuce (total number of plants commercialized each week on the property), b) 640 heads of lettuce (total number of plants in the experiment), c) 128,000 plants (total number of plants cultivated in $1 \mathrm{ha}$ ).

\begin{tabular}{lc}
\hline \multicolumn{1}{c}{ Description } & Value (U\$) \\
\hline Total for production of 2,000 plants & U\$ 149.17 \\
Total for production of 640 plants & U\$ 47.73 \\
Total for production of 128,000 plants & U $9.547,01$
\end{tabular}




\section{Results and discussion}

\section{Number of Leaves per Plant (NL)}

The increase in the $M$. javanica population reduced NL in all evaluations. In Ev1, the extreme points are represented by plants with 55 leaves and pathogen level zero, in contrast to plants with only 31 leaves, in which 9,000 individuals were discovered in the FP of M. javanica and 17 galls. In Ev2, NL varied between 31 and 55, whereas PF increased, varying from 0 to 12,000 nematodes (Figure 1) with NG varying from 0 to 15 . In Ev3, NL ranged from 21 to 47, with PF presenting a greater increase, varying from 0 to 25,000 nematodes and 0 to 38 galls. In Ev4, PF varied from 0 to 48,000, NG from 0 to 812 and NL from 18 to 28 (Figure 1). NL was reduced by $35 \%$.

\section{Stalk Weight (SW)}

The increase of FP reduced SW in all evaluations. SW, in Ev1, was $102.34 \mathrm{~g}$ for plants free of nematodes (level zero of the pathogen), since those with PF 9,000 weighed only $41.24 \mathrm{~g}$, as NG varied from 0 to 18 . In Ev2 SW, varied from 41.54 to $104.56 \mathrm{~g}$ and the nematode level from 0 to 12,000 . Plants presented an increase from 0 to 15 galls per plant. In Ev3 and Ev4, the minimum and maximum SW varied from 10.23 to $30.5 \mathrm{~g}$ and 3.67 to $29.32 \mathrm{~g}$, while FP varied from 0 to 25,000 and 0 to 48,000, respectively, while GN increased from 38 in Ev3 to 812 in Ev4 (Figure 2). SW was reduced by $87 \%$.

\section{Plant fresh material weight (FMW)}

The increase of the $M$. javanica population caused a reduction in FMW in all evaluations. In Ev1, the FMW varied from $728.49 \mathrm{~g}$ in plants with level zero of nematodes and $299.49 \mathrm{~g}$ in plants with a 9,000 PF. GN varied from 0 to 17 . The FMW variation in Ev2 was $720.34 \mathrm{~g}$ for plants free of M. javanica and $310.34 \mathrm{~g}$ for plants with 12,000 individuals, with the GN varying from 0 to 15 . varying from 0 to 15 . The FMW of Ev3 ranged from $351.54 \mathrm{~g}$ to 175.21 for the populations with 0 and 25,000 nematodes, respectively, with an NG from 0 to 38. In Ev4, PF ranged from 0 to 48,000 for plants with FMW of 440.89 and $22.07 \mathrm{~g}$, respectively, showing a 95\% reduction of FMW. NG varied from 0 to 812 (Figure 3).

In Ev1, Ev2, Ev3 and Ev4 the maximum FP were 9,000, 12,000, 25,000 and 48,000, respectively, and the maximum GN were 17, 15, 38 and 812, respectively (Figure 1). In these four evaluations reductions, were observed for all evaluated characteristics (Table 4).

\section{Estimate of yield losses}

In Table 5, note that in Ev1 and Ev2, 100\% and $99 \%$ of the plants were commercialized. In Ev3 and Ev4, 7\% and 65\% of the plants were not commercialized.

We emphasize that throughout the entire experimental period, there was no incidence of other diseases or pests in the soil and shoots. The quantified damage was the result only of nematode parasitism on the plants.

The low population of $\mathrm{J} 2 / 100 \mathrm{~mL}$ of soil (16) found before the installation of the experiment was explained by the fact that the soil had been left to fallow for four months (Table 3). Rodrigues et al. (2016) also conducted an experiment in a cultivated area with lettuce in Iúna, Brazil, which remained fallow for six months, and found on average 6.3 $\mathrm{J} 2$ of $M$. javanica $100 \mathrm{~mL}$ of soil at the beginning of the experiment. Finding these pathogens in low populations after fallow periods is common, as they do not have the preferred host to feed on. Despite this, nematodes can survive in low populations due to dormancy and their ability to feed on other plants since they are polyphagous (Hand et al., 2016).

It was observed that the population increase of $M$. javanica during the lettuce cultivation cycle caused all the growth characteristics analyzed to decrease. Taylor \& Sasser (1978) affirmed that an increase in the phytonematode population is expected since nematodes multiply on a logarithmic scale, with females producing around 500 eggs with only about 5\% surviving to complete the cycle. Over four generations, a single female can produce 25,625 , 15,625 , and 390,625 adults. It is expected that with consecutive plantings of lettuce, the level of initial inoculation $(\mathrm{Pi})$ in the soil is greater in the initial stage of each planting.

The mechanical damage caused by the nematodes penetrating and moving about in plant tissues leads to vascular tissue blockage at the feeding sites, limiting the translocation of water and nutrients, repressing plant growth and therefore the income from plant crops (Lu et al., 2014). These types of physiological and mechanical damage lead to a reduction in plant growth (Rodrigues et al., 
EV1 (Collection in July 2009)
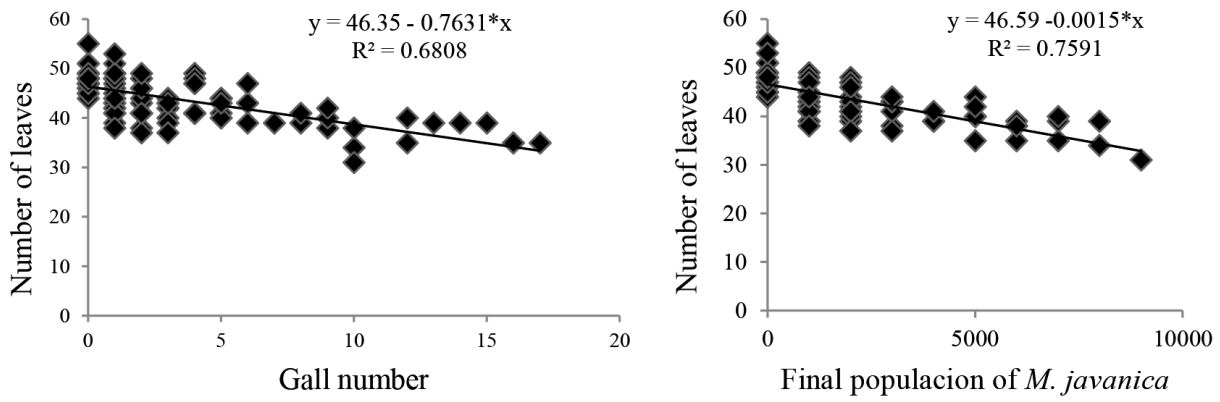

EV2 (Collection in September 2009)
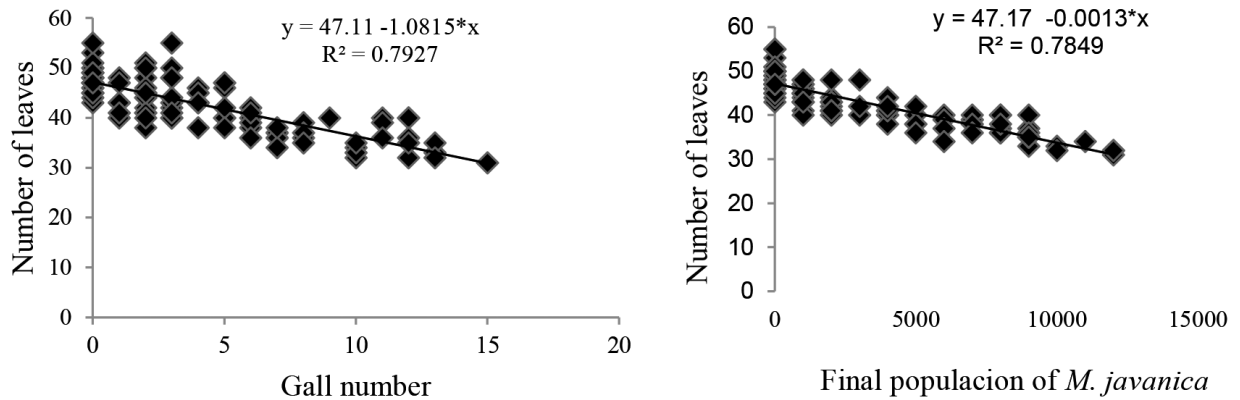

EV3 (Collection in November 2009)
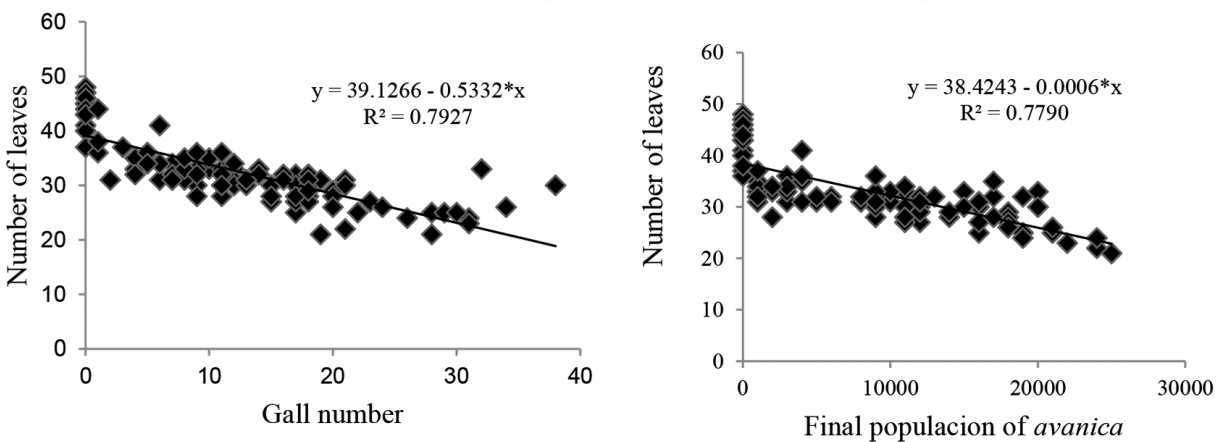

EV4 (Collection in January 2010)
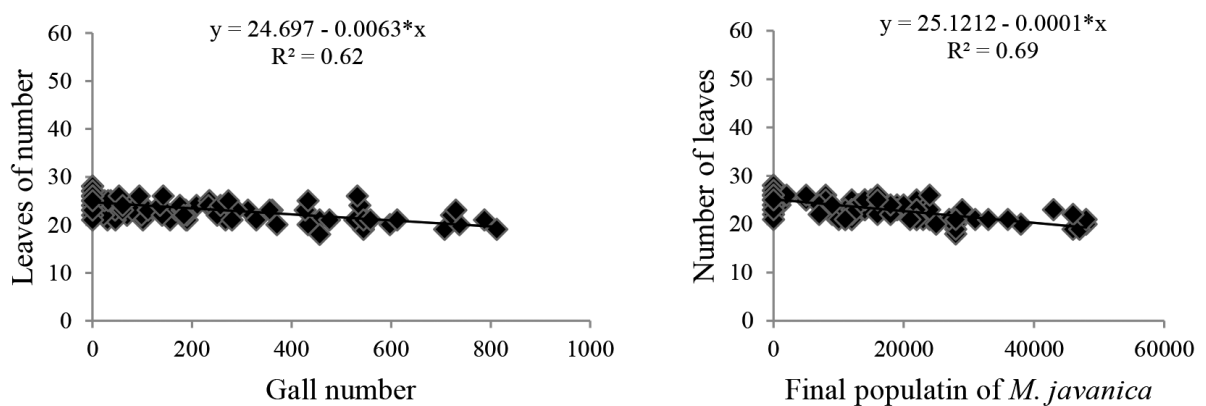

Figure 1. Number of leaves (NL) of lettuce cv. Vitória de Santo Antão as a function of the final population of M. javanica in the roots and number of galls in an area naturally infested by this pathogen in Iúna Municipality, Espírito Santo State, Brazil, in four evaluations (Ev1, Ev2, Ev3 and Ev4) done in the months of July, Sep and Nov 2009 and Jan 2010. 
EV1 (Collection in July 2009)
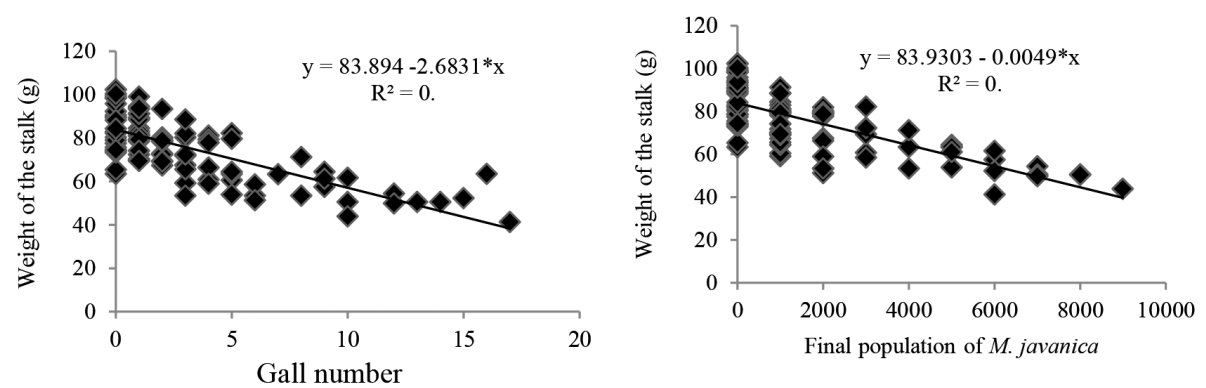

EV2 (Collection in Sept 2009)
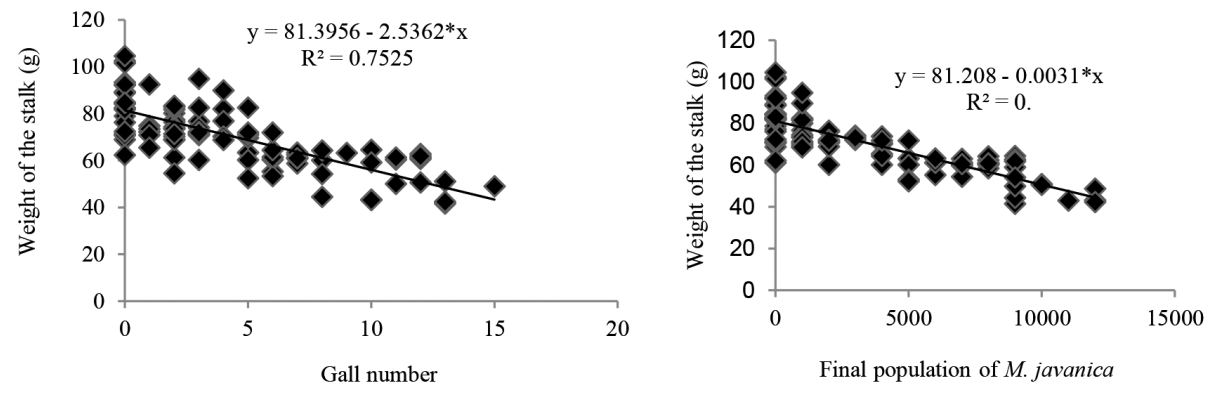

EV3 (Collection in Nov 2009)
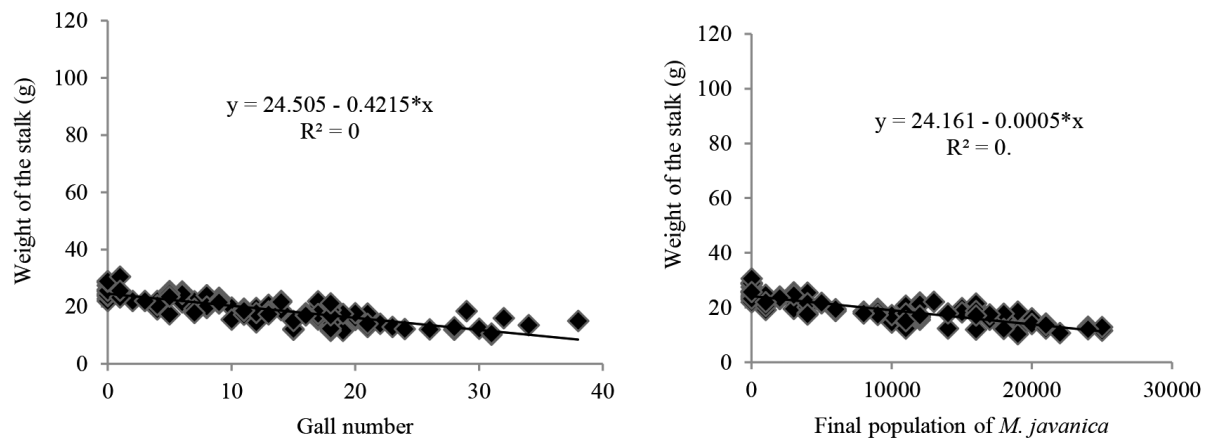

EV4 (Collection in Jan 2010)
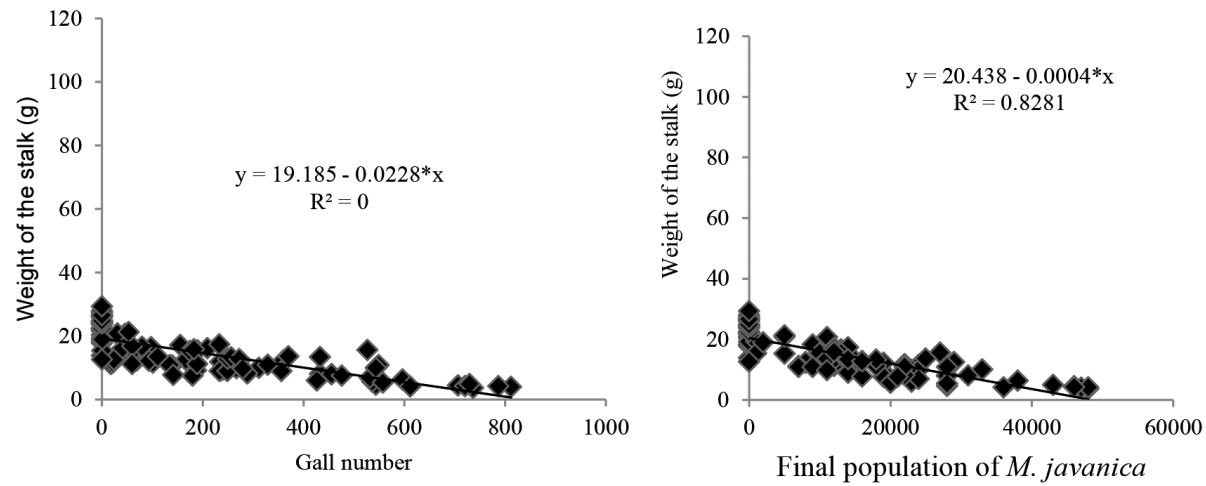

Figure 2. Stalk weight (SW) of lettuce cv. Vitória de Santo Antão as a function of the final population of $M$. javanica in the roots and number of galls, in an area naturally infested by this pathogen, in Iúna Municipality, Espírito Santo State, Brazil, in four evaluations (Ev1, Ev2, Ev3 and Ev4) done in the months of July, Sep and Nov 2009 and Jan 2010. 
EV1 (Collection in July 2009))
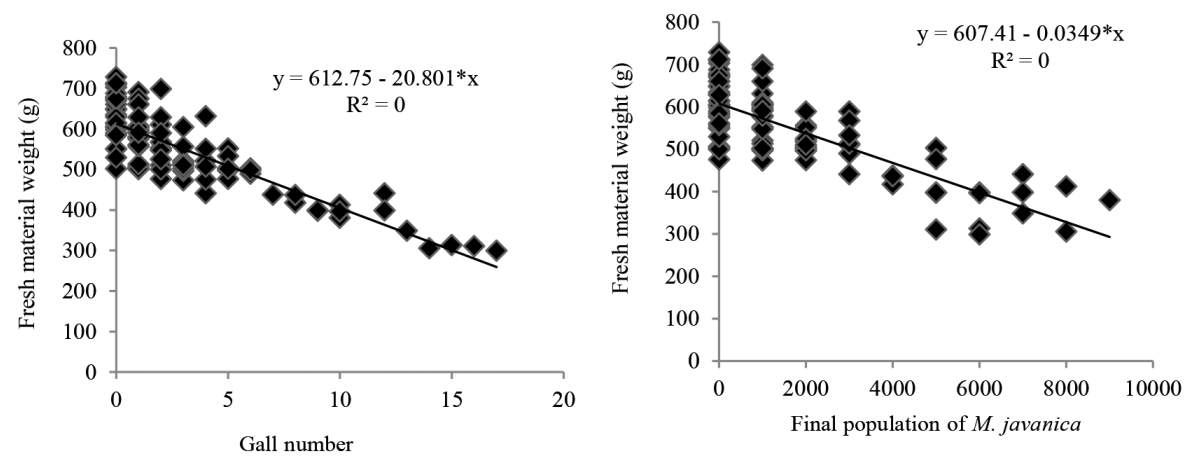

EV2 (Collection in Sept 2009)
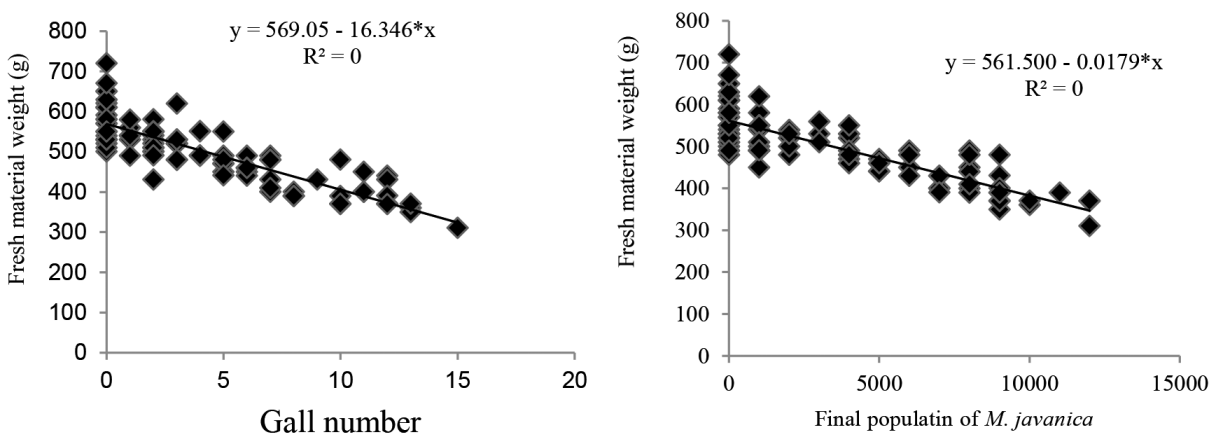

EV3 (Collection in Nov 2009)
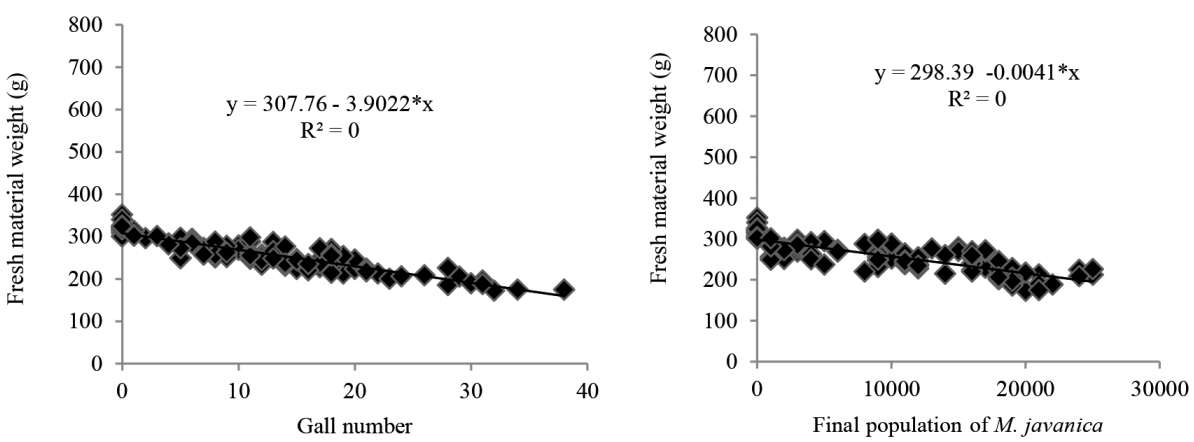

EV4 (Collection in Jan 2010)
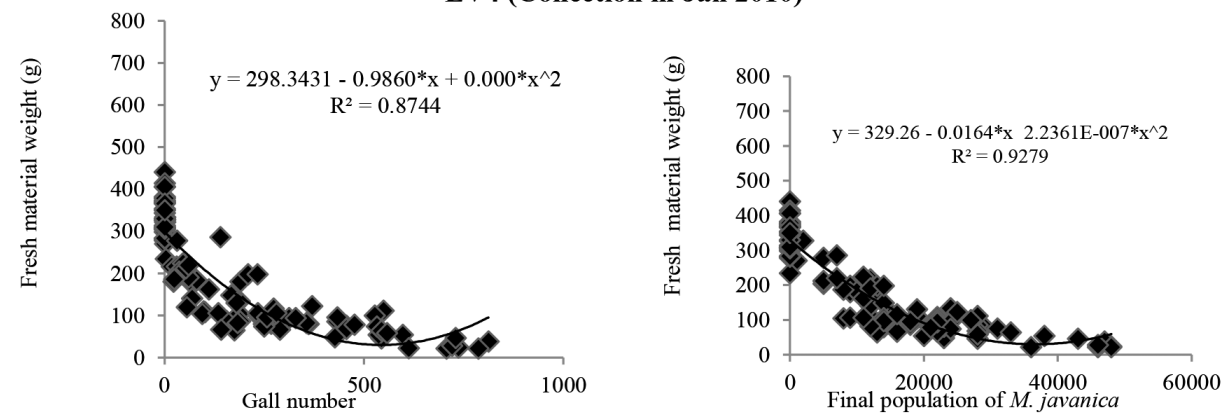

Figure 3. Fresh material weight (FMW) of lettuce cv. Vitória de Santo Antão as a function of the final population of $M$. javanica in the roots and number of galls, in an area naturally infested by this pathogen, in Iúna Municipality, Espírito Santo State, Brazil, in four evaluations (Ev1, Ev2, Ev3 and Ev4) done in the months of July, Sep and Nov 2009 and Jan 2010. 
Table 3. Initial population of Meloidogyne javanica (Pi) expressed in number of second stage juveniles (J2) in $100 \mathrm{~mL}$ of soil in the experimental area before beginning the experiment.

\begin{tabular}{cccccc}
\hline & Seedbed $1 *$ & Seedbed 2 & Seedbed 3 & Seedbed 4 & Average \\
\hline & 20 & 28 & 28 & 28 & 26 \\
& 21 & 25 & 27 & 29 & 26 \\
& 16 & 32 & 28 & 32 & 27 \\
Average & 24 & 27 & 20 & 24 & 24 \\
& 28 & 19 & 19 & 25 & 23 \\
& 16 & 24 & 32 & 31 & 26 \\
\hline
\end{tabular}

* Thirty soil samples were collected at a depth 0-20 cm randomly in each of four seedbed, mixed and homogenized, forming 4 composite samples from the 30 single samples per seedbed.

Table 4. Reductions in fresh material weight (FMW) and dry (DMW) in lettuce cv. Vitória de Santo Antão parasitized by $M$. javanica in four evaluations

(Ev1, Ev2, Ev3 and Ev4) done in the months of July, Sep and Nov of 2009 and Jan 2010 compared to plants free of nematodes (level zero of the pathogen).

\begin{tabular}{ccccc}
\hline \multirow{2}{*}{ Characteristics evaluated } & \multicolumn{4}{c}{ Reductions observed (\%) } \\
\cline { 2 - 5 } & EV1 & EV2 & EV3 & EV4 \\
\hline \multirow{2}{*}{ FMW } & 59 & 57 & 50 & 95 \\
DMW & 55 & 51 & 57 & 83 \\
\hline
\end{tabular}

2016), agreeing with the results in this study, in which in the fourth consecutive planting (Ev4), only $35 \%$ of the cultivated lettuce plants were above the acceptable weight for market consumption. According to Abd-Elgaward \& Askary (2015), the root-knot nematodes may reduce production by up to $86 \%$, depending on the intensity of the infestation and the cultivated plants.

The succession of lettuce plantings contributed to the increase in the number of plants with levels of damage that resulted in plants below the commercially accepted weight. With only two consecutive plantings, significant damage was not observed; in other words, the pathogen did not reach populations capable of causing significant damage.

In three sequential plantings (Ev1, Ev2, and Ev3), the crops presented perceptible damages, albeit at a low level ( $7 \%$ of plants below the commercially acceptable weight in Ev3), which do not prevent cultivation nor significantly reduce income, meaning the nematode has not yet been characterized as a phytopathological hindrance to the commercial cultivation of the lettuce.
Table 5. Percentage of lettuce plants cv. Vitória de Santo Antão capable of being commercialized when cultivated in an area naturally infested by $M$. javanica in the Iúna

Municipality in Espírito Santo State, Brazil in four evaluations (Ev1, Ev2, Ev3 and Ev4) done in the months of July, Sep and Nov 2009 and Jan 2010. Plants with a fresh material weight (FMW) higher than $200 \mathrm{~g}$ were considered able to be commercialized.

\begin{tabular}{lrrcr}
\hline \multirow{2}{*}{ Evaluation } & \multicolumn{4}{c}{ FMW (\%) } \\
\cline { 2 - 5 } & $\geq 300$ & 200.01 a 300 & 100.01 a 200 & $\leq 100$ \\
\hline Ev1 & 100 & 0 & 0 & 0 \\
Ev2 & 99 & 1 & 0 & 0 \\
Ev3 & 18 & 75 & 7 & 0 \\
Ev4 & 24 & 11 & 30 & 35 \\
\hline
\end{tabular}

The ET concept is specific for each crop and is based on the disease intensity at which the benefits of control are equal to the cost. Costs above this level are characterized as yield losses. In the present study, the ET in Ev4 was 10,151 nematodes/plant or 109 galls/plant. In the study by Potter \& Olthof (1974), the ETs for beet, spinach, and lettuce crops were $17 \%, 13 \%$, and $10 \%$, respectively. In the present study, the reduction of lettuce FMW reached $93 \%$ in plants parasitized by 48,000 individuals of $M$. javanica, in agreement with the results of Potter \& Olthof (1974), who observed a reduction of $81 \%$ in plants parasitized by M. hapla Chitwood, 1949.

In the study by Chen et al. (1999), M. hapla caused a 178 to $103 \mathrm{~g} /$ plant reduction in lettuce, corresponding to 21 and 17\% in 1995 and 1996, respectively. In Ev4 in the present study, DMW oscillated between $18.97 \mathrm{~g}$ and 3.21 for an FP that 
Table 6. Estimate of yield losses (U\$) in area of commercial planting of lettuce cv. Vitória de Santo Antão in Iúna Municipality, Espírito Santo State, Brazil, cultivated in the presence of $M$. javanica in four evaluations (Ev1, Ev2, Ev3 and Ev4) done in the months of July, Sep and Nov 2009 and Jan 2010.

Only plants weighing more than $200 \mathrm{~g}$ were considered suitable for commercialization.

\begin{tabular}{|c|c|c|c|c|c|c|}
\hline \multirow{2}{*}{$\begin{array}{l}\text { Number } \\
\text { of plants }\end{array}$} & \multicolumn{3}{|c|}{$\begin{array}{c}\text { Ev1 } \\
(100 \% \text { of plants commercializable })\end{array}$} & \multicolumn{3}{|c|}{$\begin{array}{c}\text { Ev2 } \\
\text { (99\% of plants commercializable) }\end{array}$} \\
\hline & $\begin{array}{l}\text { Sales/production } \\
\text { (U\$) }\end{array}$ & $\begin{array}{l}\text { Costs/production } \\
\text { (U\$) }\end{array}$ & $\begin{array}{l}\text { Profit/producer } \\
\text { (U\$) }\end{array}$ & $\begin{array}{l}\text { Sales/production } \\
\text { (U\$) }\end{array}$ & $\begin{array}{l}\text { Costs/production } \\
\text { (U\$) }\end{array}$ & $\begin{array}{l}\text { Profit/producer } \\
\text { (U\$) }\end{array}$ \\
\hline $640 *$ & 115.17 & 47.73 & 67.44 & 114.99 & 47.73 & 67.26 \\
\hline $2,000^{* *}$ & 359.92 & 149.17 & 210.75 & 359.91 & 149.17 & 210.57 \\
\hline \multirow[t]{3}{*}{$128,000^{* * * *}$} & $23,035.39$ & $9,054.00$ & $13,488.90$ & $23,035.37$ & $9,546.49$ & $13,488.72$ \\
\hline & \multicolumn{3}{|c|}{$\begin{array}{c}\text { Ev3 } \\
\text { (93\% of plants commercialized) }\end{array}$} & \multicolumn{3}{|c|}{$\begin{array}{c}\text { Ev4 } \\
\text { (35\% of plants commercialized) }\end{array}$} \\
\hline & $\begin{array}{l}\text { Sales/production } \\
\text { (U\$)(U\$) }\end{array}$ & $\begin{array}{l}\text { Costs/production } \\
\text { (U\$) }\end{array}$ & $\begin{array}{l}\text { Profit/producer } \\
\text { (U\$) }\end{array}$ & $\begin{array}{l}\text { Sales/production } \\
\text { (U\$) }\end{array}$ & $\begin{array}{l}\text { Costs/production } \\
\text { (U\$) }\end{array}$ & $\begin{array}{l}\text { Profit/producer } \\
\text { (U\$) }\end{array}$ \\
\hline 640 & 107.11 & 47.73 & 59.38 & 40.31 & 47.73 & -7.42 \\
\hline 2,000 & 334.73 & 149.17 & 185.76 & 125.97 & 149.17 & -23.19 \\
\hline 128,000 & $21,422.92$ & $9,546.49$ & $11,876.42$ & $8,062.38$ & $9,546.49$ & $-1,484.10$ \\
\hline
\end{tabular}

*Total number of plants in the experimental area.

** Total number of plants commercialized per week by the farmer.

*** Total number of plants cultivated in 1 ha.

varied from 0 to 48,000; in other words, DMW and FMW were reduced by 83.07 and $95 \%$, respectively.

In the fourth planting (Ev4), the FP was already high in the area, to the point of causing considerable damage to the lettuce crop, rendering $65 \%$ of the plants unviable for sale. This demonstrates the risk of carrying out four sequential lettuce plantings in the same area since, in the last planting, the cost of production will exceed the commercial value of the plants. Thus, it is clear that in the most studied area, lettuce cv. Vitória de Santo Antão can be grown for three consecutive cycles, after that different management strategies should be considered, such as leaving land fallow, rotating the crop, implanting a crop that is not susceptible to $M$. javanica, or even cultivating lettuce resistant to the pathogen. Production of lettuce cv. Vitória de Santo Antão may be resumed when the initial nematode soil population is reduced.

It is important to emphasize that plants weighing less than $200 \mathrm{~g}$ are not commercially valuable, and the estimated values of loss are valid for the period in which the experiment was developed.

The first step was to calculate the costs of producing lettuce plants to make this estimate. To do this, we considered all of the raw materials, labor, work, and equipment costs in preparing seedlings, the plantation, irrigation, fertilization, and commercialization, as well as the depreciation of the machinery.

Until the third planting, the farmer will profit from commercially exploiting crops of lettuce cv. Vitória de Santo Antão on his property in Iúna, because in the first two plantings (Ev1 and Ev2), there were no yield losses due to the occurrence of the nematodes, and in the third crop (Ev3), 93\% of the plants were sold, justifying the cultivation of the lettuce.

In Ev3, the net gain was reduced compared to Ev1 and Ev2 (only U\$ 1.612,47). Nevertheless, it was worth cultivating the plants because the producer made profits of U\$59.38. U\$ 185.56 and U\$ $11,876.42$, considering the crop sizes of 640 , 2,000 , and 128,000 plants, respectively.

The lettuce's fourth cycle (Ev4) was shown to be completely unviable since the produce had losses of U\$ 7.42; U\$ 23.19, and U\$ $1,484.10$ for cultivating $640,2,000$, and 128,000 plants, respectively.

Higher air temperatures and precipitation were observed in the last two cycles of lettuce (EV3 and EV4), which contributed to the significant population increase of $M$. javanica compared to EV1 and EV2, when air temperatures and precipitation did not exceed $24^{\circ} \mathrm{C}$ and $53 \mathrm{~mm}$, respectively. Thus in EV1 and EV2, the cycle of M. javanica was longer since, at lower temperatures, the cycle of 
the nematode can reach 60-70 days (Bird, 1974). According to the author, this variation is due to the reduction of the speed of the enzymatic reactions in the various events of the development of the nematode. Furtherore, under optimum temperature conditions, Meloidogyne spp. complete their cycle in 28 days (Bird, 1959).

It is important to emphasize that at higher temperatures (EV3 and EV4), there is a greater penetration of $M$. javanica juveniles into lettuce roots and significant $\mathrm{J} 2$ outbreaks (Khan et al., 2014). Morris et al. (2011) observed that the percentage of $\mathrm{J} 2$ of Meloidogyne spp. was significantly lower at $15^{\circ} \mathrm{C}$ than at 20 and $25^{\circ} \mathrm{C}$, with the fastest hatching occurring at $23^{\circ} \mathrm{C}$. The mean temperatures recorded in our study in EV3 and EV4 were 21 and $26.5^{\circ} \mathrm{C}$, respectively.
Nematodes require minimal oxygen content in the soil so they can develop their cycle normally. Therefore, prolonged saturation conditions reduce of some nematode species by excess water, limiting movement and hatching, and favoring the production of toxins by anaerobic organisms (Kitazume et al., 2018). Although pluviometric indexes were higher in EV3 and EV4 (214 and $255 \mathrm{~mm}$, respectively), there was no prolonged period of precipitation, and the higher soil moisture in these last two lettuce cycles favored the population increase of $M$. javanica.

Many studies have been done to quantify the damage to lettuce parasitized by Meloidogyne spp. (Viaene \& Abawi, 1998; Chen et al., 1999). Many of these works mention that these pathogens cause yield losses; however, they do not systematically quantify the yield losses, as carried out in the present work.

\section{Literature cited}

Abb-Elgaward, M.M.M.; Askary, T.H.

2015. Impact of phytonematodes on agriculture economy. In: Askary, T.H.; Martinelli, R.P. (eds). Biocontrol Agents of Phytonematodes. CAB International. Boston, US. pp. 3-49.

Bird, A.F.

1974. Plant response to root-knot nematodes. Annual Review of Phytopathology, 12: 69-85.

Bird, A.F.

1959. Development of the root-knot nematodes Meloidogyne javanica (TREUB) and Meloidogyne hapla (Chitowood) in the tomato. Nematologica 4: 31-42.

Bonetti, J.I.; Ferraz, S.

1981. Modificações do método de Hussey e Barker para extração de ovos de Meloidogyne exigua em raízes de cafeeiro. In: CONGRESSO BRASILEIRO, 3. Anais.. Brasília: SBF. p. 553.

Carneiro, R.M.D.G.; Almeida, M.R.A.

2001. Técnica de eletroforese usada no estudo de enzimas dos nematoides de galhas para identificação de espécie. Nematologia Brasileira 25: 555-560.

CEASA-ES

2018. Espírito Santo Supply Centers. Avaliable at: https:// ceasa.es.gov.br. Acessed on: Mar 01.

Chen, J.; Abawi, G.S.; Zuckerman, B.M.

1999. Suppression of Meloidogyne hapla and Its damage to lettuce grown in a mineral soil amended with chitin and biocontrol organisms Supplement to the Journal of Nematology, 31: 719-725.

Hand, S.C.; Denlinger, D.L.; Podrabsky, J.E.; Roy, R.

2016. Mechanisms of animal diapause: recent developments from nematodes, crustaceans, insects, and fish. Am. J. Physiol. Regul. Integr. Comp. Physiol., 310: 1193-1211.

Jenkins, W.R.A.

1964. A rapid centrifugal-flotation technique for separating nematodes from soil. Plant Disesase Report, 48: 692.
Jesus Junior, W.C.; Alves, F.R.; Zambolim, L.

2014. Quantificação de danos e perdas: case study. In: Zambolim, L.; Jesus Jr, W.C.; Rodrigues, F.A. (Eds.) O essencial da fitopatologia, a epidemiologia de doenças de plantas. Viçosa, BRA, Universidade Federal de Viçosa. pp. 33-48.

Khan, A.; Wesemael, W.; Moens, M.

2014. Influence of temperature on the development of the temperate root-knot nematodes Meloidogyne chitwoodi and M. fallax. Russian Journal of Nematology, 22 (1): 1-9.

Kitazume, H.; Dayi, M.; Tanaka, R.; Kikuchi, T.

2018. Assessment of the behaviour and survival of nematodes under low oxygen concentrations PLOS ONE. 14: 1-12.

LU, P.; Davis, R.F., Kemerait, R.C.; Iersel, M.W.V.; Scherm, H. 2014. Physiological Effects of Meloidogyne incognita infection on cotton genotypes with differing levels of resistance in the greenhouse. Journal of Nematology, 46(4): 352-359.

Morris, K.S.; Horgan, F.G.; Downes, M.J.; Griffin, G.T.

2011. The effect of temperature on hatch and activity of secondstage juveniles of the root-knot nematode, Meloidogyne minor, an emerging pest in north-west Europe. Nematology, 13(8): 985-993.

Potter, J.W.; Olthof, T.H.A.

1974 Yield losses in fall-maturing vegetables relative to population densities of Pratylenchus penetrans and Meloidogyne hapla. Phytopatology, 64: 1072-1075.

Rodrigues, L.L.; Alves, F.R.; Chagas, E.N.; Camara, G.R.; Silva, G.A.; Jesus Junior, W.C.; Moraes, W.B.

2016. Management of Meloidogyne javanica with biological pesticides and oils in a lettuce field. Nematoda, 3: 01-09.

Taylor, A.L.; Sasser, J.N.

1978 Biology, identification and control of root-knot nematodes (Meloidogyne ssp.). North Carolina State University Graphics. Raleigh, NC, US. 111 p.

Viaene, N.M.; Abawi, G.S.

1998. Management of Meloidogyne hapla on lettuce in organic soil with sudangrass as a cover crop. Plant Disease, 82: 945-952. 